\section{Henry David Thoreau: Deep Ecologist?}

\author{
Don Mortland \\ Lexington, Kentucky
}

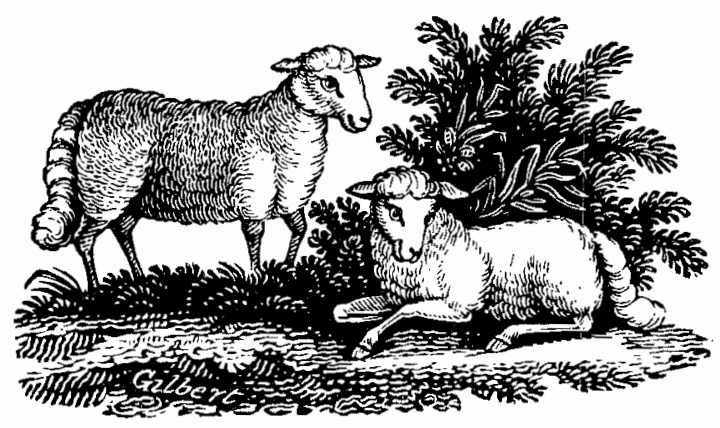

At the beginning of his essay "Walking," Henry David Thoreau states that he wishes "to make an extreme statement, if so I may make an emphatic one" (597). I would like to do likewise in this paper, albeit without Thoreau's symbolic subtlety and metaphorical sophistication. My message is simple: It behooves environmentalists to read Thoreau a little more carefully, particularly the "Higher Laws" chapter of Walden, before they choose him as a crusader for their cause. As Wendell Berry suggests,

Thoreau has been adopted by the American environment movement as a figurehead; he is customarily quoted and invoked as if he were in some simple way a forerumner of environmentalism. This is possible, obviously, only because Thoreau has been dead since 1862 . Thoreau was an environmentalist in exactly the sense that Edward Abbey is: he was for some things that environmentalists are for. And in his own time he was just as much of an embarrassment to movements, just as uncongenial to the group spirit, as Edward Abbey is, and for the same reasons: he was

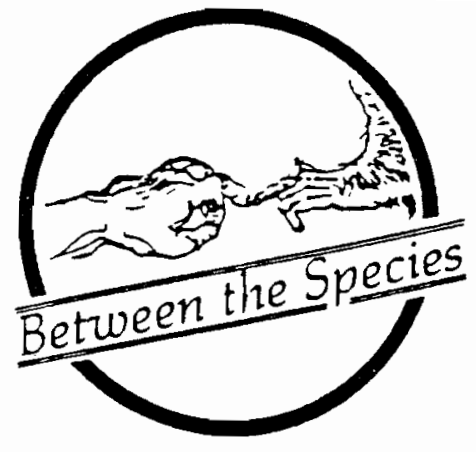

working as an autobiographer, and his great effort was to conserve himself as a human being in the best and fullest sense (40).

I doubt that Thoreau would be happy to be compared in some ways to Edward Abbey, ${ }^{1}$ but Berry does seem to get to the essence of what Thoreau was about--and that was a reform that went far beyond the concerns of most environmentalists today.

Thoreau wrote much and it is, of course, easy for environmentalists of every stripe to find something of his to quote in support of their position. At the risk of some oversimplification, I shall divide contemporary environmentalists into two camps and suggest how each is likely to use Thoreau. First are those basically anthropocentric movements or organizations embodying what have been called variously "shallow," "dominant world view," "reformist" or "New Age/Aquarian" environmentalist positions. ${ }^{2}$ Such organizations as The Audubon Society, The Wilderness Society, the National Wildlife Federation and the Sierra Club would be in this camp. They believe that nature exists to serve man and promote environmental issues only in so far as they see such benefit ensuing. It is difficult to imagine how Thoreau, aside from sharing with some members of these groups a love of the beauty of nature, would have much in common with them. Yet he occasionally reflects a position very similar to theirs. For instance, in a journal

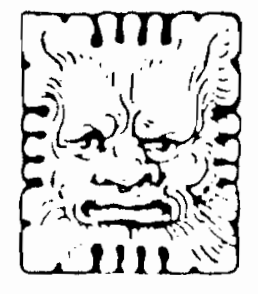


entry of June 13, 1853, Thoreau records why he tells a farmer friend that he doesn't want him to shoot a chicken hawk:

I would rather save one of these hawks than have a hundred hens and chickens. It was worth more to see them soar, especially now that they are so rare in the landscape.... It is unnecessary to sacrifice the greater value to the less. I would rather never taste chickens' meat nor hens' eggs than never to see a hawk sailing through the upper air again (V 246).

Here a hawk-or a chicken, for that matter-is valued not according to its inherent worth but instead for its aesthetic value to mankind. Other such statements could be found in the Journals, but I don't believe they represent the considered judgment he gave us in his finished books and essays.

The other environmentalist camp with which Thoreau is associated, and increasingly so, is like deep ecologists. ${ }^{3}$ Some of those aligned with this camp are Arne Naess, Murray Bookchin, George Sessions, Bill Devall and Michael Tobias, and such groups as Earth First! Whatever the diverse beliefs of these people and groups, they seem united in at least two fundamental positions: (1) The only ultimate solution to an improved environment is a great reduction in the human population; and (2) The need to recognize that we live in a biocentric universe in which man has no more inherent rights to survival than other plant and animal species. Nature is not a resource for man's use but is of intrinsic value for itself. In short, theirs is a non-anthropocentric view of the universe.

As to the population problem, we cannot expect to find Thoreau having much to say of this, as it was not perceived as a problem in his day. But the deep ecologists have little trouble enlisting the Concordian's support for the intrinsic worth of nature as opposed to its value as a human resource. A couple examples should illustrate his proximity to their position. The most famous is the "pine tree" matter, which had been published first in the Atlantic and later posthumously in The Maine Woods. After denying that the lumberman, the tanner or the turpentiner-all of whom have interest in the pine tree as a resource-have no understanding of its intrinsic nature, he goes on to say,

No! No! it is the poet; he it is who makes the truest use of the pine-who does not fondle it with an ax, nor tickle it with a saw, nor stroke it with a plane,- - who knows whether its heart is false without cutting into it.... No, it is the poet, who loves them as his own shadow in the air, and lets them stand.

He further adds, "It is the living spirit of the tree, not the spirit of turpentine, with which I sympathize, and which heals my cuts. It is as immortal as I am, and perchance will go to as high a heaven, there to tower above me still" (88-89). Deep ecologists were, of course, unheard of in Thoreau's day, but it is this last sentence, placing man on an equal plane with nature, that appeals to them today. (This sentence so offended James Russell Lowell, the Atlantic editor, that he deleted it from the published version of the original essay, "Chesuncook," thereby acquiring the lifelong enmity of Thoreau (Harding 393-94).)

Another example of Thoreau's sympathy with the deep ecology position may be found in the Billerica dam episode of $A$ Week on the Concord and Merrimac Rivers. Here he laments the fate of the shad whose instinct to fulfill their natural migration is prevented by man's building of a dam for his own selfish ends. After stating "what may avail a crow-bar against that Billerica dam?," and thus anticipating the practice of the late Edward Abbey and other Earth First! monkeywrenchers, he concludes,

Away with the superficial and selfish philanthropy of men.... Who hears the fishes when they cry? It will not be forgotten by some memory that we were contemporaries. Thou shalt ere long have thy way up the rivers, up all the rivers of the globe, if I am not mistaken. Yea, even thy dull watery dream shall be more than realized. If it were not so, but thou wert to be over-looked at first and at last, then would I not take their heaven (40).

Here again man's heaven is equated with that which recognizes the intrinsic worth of all creatures. ${ }^{4}$

However, while Thoreau can be used judiciously by deep ecologists as one sympathetic to many of their viewpoints, there is yet a crucial difference between them, a difference which I believe well articulated by Dave Foreman when he draws a distinction between animal rights and deep ecology: 
Animal Rights is based on a concern for the well-being of individual creatures foremost. Deep Ecology is ecological, recognizing that life depends on life, that some suffering and pain is inherent in nature, that death is not evil; Animal Rights is compassionate, desiring to eliminate suffering and pain, and is, if taken to its logical extreme, anti-death. Deep Ecology is naturalistic, believing that nature knows best, going beyond good and evil to simply letting being be: Animal Rights in its more extreme forms is anti-nature, arguing that although "primitive" peoples may have eaten meat, we as civilized humans have advanced to a point where we can change our animal natures and operate on an ethical basis, to even claiming that nature is not perfect...(146)

If the latter part of Foreman's remarks seem somehow familiar, an echo of something that we long ago heard, may I suggest that we turn to the "Higher Laws" chapter of Walden to refresh our memories: (1) "... I have no doubt that it is a part of the destiny of the human race, in its gradual improvement, to leave off eating animals, as surely as the savage tribes have left off eating each other when they came in contact with the more civilized"(194); (2) "We are conscious of an animal in us, which awakens in proportion as our higher nature slumbers"(197); (3) "He is blessed who is assured that the animal is dying out in him day by day, and the divine being established"(197-98); (4) "Nature is hard to overcome, but she must be overcome"(198). In short, these statements from "Higher Laws" align Thoreau more closely with the animal rights' position than with the deep ecologists'.

I am, of course, aware of the controversy that swirls around "Higher Laws," aware of what Frederick Garber calls the "markedly schizophrenic" quality of the chapter as evidenced by the supposed conflict between the quotations above and his desire to eat woodchucks raw or devour fried rats (120). But the overall thrust of "Higher Laws" and the corpus of Thoreau's other writings suggest that he did believe in a spiritual and moral development that would enable man to transcend nature as it is. He was, after all, a transcendentalist, and, as Donald Worster has observed, this movement

... placed little value on nature in and of herself; indeed the transcendentalist was as often repulsed by this slimy, beastly world as any good Christian. The lower order was not coequal with the higher realm of spirit; it was inferior, blemished, incomplete. Rather than looking deeper into nature to find the divine spark, the transcendentalist raised his eyes above this unsatisfying life toward a vision of serene and immortal harmony. In this mood, Thoreau could write: "Our ideal is the only real" (100).

It may well be that Worster's statement is a little too extreme with regard to Thoreau, that it deprecates too much the very real love Thoreau had for nature regardless of how red in tooth and claw it might be. He did, after all, say in the first paragraph of "Higher Laws" that "I found in myself, and still find, an instinct toward a higher, or, as it is named, spiritual life, as do most men, and another toward a primitive rank and savage one, and I reverence them both"(189), What is often overlooked, though, are the implications of the sentence immediately following the above: "I love the wild not less than the good." As Garber has pointed out

... the words are a strange pair to be offered as opposites. The contrary of the wild is ordinarily the tame, not the good. The contrary of the good is ordinarily evil, not the wild. To contrast the wild and the good is, it would appear, to link the good with the tame and the wild with evil...(115).

Thoreau was too careful a writer and thinker not to know what he was about here, and it seems to me he is suggesting that you can simultaneously "reverence" two positions yet recognize the moral superiority of the one over the other.

And Thoreau was an honest writer, one honest enough to let the "schizophrenic" qualities of his own character appear in his work. He recognized the "animal within" and he confronted it. As Robert Epstein has noted, "... we need to become conscious of primitive desires and impulses within us. It is Thoreau's conviction that higher consciousness, that is to say, selfknowledge, leads to increased spirituality and discipline"(26). In "Higher Laws" Thoreau is dealing with his practice and his theory, the way he is and the way he wishes he were. His own experience with vegetarianism reflects this conflict. He leaves no doubt 
that the vegetarian life is his preference, but as many scholars have noted, Thoreau could not in his own life achieve the ideal of a completely vegetarian diet. ${ }^{5}$

But he did want in Walden to be certain that his readers understood that there were "higher laws" to emulate than those embodied in nature. His revisions of the "Higher Laws" chapter over the at least seven years he worked on the book are revelatory. The first version, no doubt written while at Walden Pond, sets forth clearly his desire to live a "life in conformity to higher principles," but the principles are "a little stardust caught" and do not directly conflict with nature-either human or nonhuman-as it exists. It is only in the fourth and fifth versions and after years of thought that he included the material about nature needing to be overcome, in what was no doubt an effort to clarify just what must be sacrificed to attain to a life lived by higher principles. ${ }^{6}$

A life lived according to higher principles, the little star-dust caught, the castles built in the air-it is these urgings for man to lift himself above nature to some more perfect, more ideal plane, that differentiate Thoreau from most of today's environmentalists. This is not to say that Thoreau did not love nature as it is or that environmentalists of diverse stripes are unjustified in quoting his remarks relevant to their particular arguments. He certainly wrote much about nature and some of this is compatible with the beliefs of even the most anthropocentric of environmentalists today. But I think I am correct in assuming that the "Higher Laws" chapter of Walden represents his most carefully thought out statement of man's relation to nature. If so, then he has most in common with the deep ecologists who believe that nature is an end in itself and not just a good in so far as it serves mankind, whether that be for economical, aesthetic or any other ends. But, on the other hand, he, unlike the deep ecologists, feels that nature is something that ultimately must be overcome, that man has the potential to rise above nature to a higher spiritual plane. To repeat what I said earlier, Thoreau is, in the final analysis, and unlike the deep ecologists, a transcendentalist.

\section{References}

Abbey, Edward. "Down the River with Henry Thoreau." 1981. Words from the Land: Encounters with Natural History Writing. Ed. Stephen Trimble. Salt Lake City: Gibbs Smith, 1988, 50-76.
Altherr, Thomas L. " 'Chaplain to the Hunters': Henry David Thoreau's Ambivalence Toward Hunting." American Literature 56(1984): 345-61.

Berry, Wendell. "A Few Words in Favor of Edward Abbey." What Are People For?: Essays by Wendell Berry. San Francisco: North Point, 1990. 36-47.

Deep Ecology. Ed. Michael Tobias. 2nd. ed. San Marcos, CA: Avant Books, 1988.

Devall, Bill. Simple in Means, Rich in Ends: Practicing Deep Ecology. Salt Lake City: Gibbs Smith, 1988.

-, and George Sessions. Deep Ecology: Living as if Nature Mattered. Salt Lake City: Gibbs Smith, 1985.

Dombrowski, Daniel A. “Thoreau, Sainthood and Vegetarianism." American Transcendental Quarterly 60(1986): 25-36.

Engel, J. Ronald. "Teaching the Eco-Justice Ethic: The Parable of the Billerica Dam." The Christian Century 104(1987): 466-69.

Epstein, Robert. "Thoreau's 'Higher Laws' and the Heroics of Vegetarianism," Between the Species 1.3(1985): 23-28.

Foreman, Dave. qtd in Christopher Manes, Green Rage: Radical Environmentalism and the Unmaking of Civilization. Boston: Little, Brown, 1990.

Friesen, Victor Carl. The Spirit of the Huckleberry: Sensuousness in Henry Thoreau. Edmonton, Alberta: Univ. of Alberta P, 1984.

Garber, Frederick. Thoreau's Redemptive Imagination. New York: New York U P, 1977.

Harding, Walter. The Days of Henry Thoreau. New York: Knopf, 1965.

McIntosh, James. Thoreau as Romantic Naturalist. Ithaca: Cornell U P, 1974.

Shanley, J. Lyndon. The Making of Walden. Chicago: Univ. of Chicago P. 1957.

Thoreau, Henry David. Joumal of Henry David Thoreau. Ed, Bradford Torrey and Francis H. Allen. 14 vols. (1906; rpt. Salt Lake City: Peregrine Smith, 1984).

-. The Maine Woods. 1864. New York: Bramhall House, 1950.

- Walden and Other Writings of Henry David Thoreau. Ed. Brooks Atkinson. New York: Modern Library, 1950.

—. "Walking." Walden and Other Writings of Henry David Thoreau: 597-632. 
- A Week on the Concord and Merrimack Rivers. 1849 Orleans, MA: Parnassus Imprints, 1987.

Worster, Donald. Nature's Econony: A History of Ecological Ideas. Cambridge, MA: Cambridge U P, 1977.

\section{Notes}

${ }^{1}$ While Abbey had great respect for much of what Thoreau stood for, I doubt that the latter would have felt comfortable with such a garrulous, hedonistic sensualist as Edward Abbey, particularly the Abbey who wrote "Down the River with Henry Thoreau," an essay in which he ridicules Thoreau for his striving for purity and calls "Higher Laws" the "most unctuous of his many sermons" $(55)$. That sensuousness played a large part in Thoreau's life is amply demonstrated by Victor Carl Friesen, but it is a more refined, sophisticated sensuousness than that associated with Edward Abbey.

${ }^{2}$ Discussions of these anthropocentric movements may be found in the first chapters of Devall and Sessions' Deep Ecology and Devall's Simple in Means, Rich in Ends.

${ }^{3}$ In addition to the works of Devall and Devall and Sessions already mentioned, see Deep Ecology, edited by Michael Tobias, for an overview of the deep ecology position. The latter work is particularly interesting because it presents essays by a diverse group of people, some of whom are only tangentially related to the deep ecology movement.

${ }^{4}$ For a sensitive but basically anthropocentric view of this passage, see Engel.

${ }^{5}$ Much has been written recently on Thoreau's vegetarianism and his treatment of animals in general. Most seem to agree that he preferred the vegetarian life as the ideal. See Epstein and Dombrowski. A meaningful discussion of his ambivalence tow ard hunting is presented by Altherr.

${ }^{6}$ See Shanley for an analysis of the seven versions of Walden written over a seven to nine year period. James McIntosh, while believing that Thoreau never completely resolved the conflict between the simultaneous attractions of the laws of nature and higher laws(247-52), does concede that "In the process of composition Thoreau has grown less anxious to write of himself as a part of nature, more intent on asserting his intelligent separateness"(252)

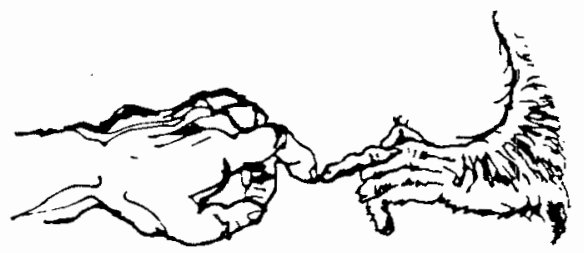

\section{Concerned about:}

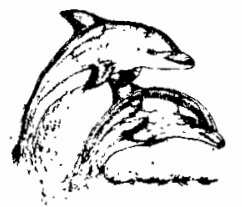

Furs?

Zoos?

Hunting?

Trapping?

Vivisection?

Factory Farming?

Wildlife Conservation?

\section{WE ARE TOO....}

Did you know that philosophers have also made a contribution to the growth of the animal liberation movement?--Think of Clark, Magel, Regan, Rollin, Singer and Sapontzis.

Between the Species "is the only publication which allows such extensive examination of the philosophical basis for animal rights."- Brad Miller, Humane Farming Association.

Subscribe today-and please send your tax deductible contribution-help us guarantee philosphers a forum in which to continue to evolve a sound basis for animal rights.

\section{$\$ 16.00$ from:}

\author{
Between the Species \\ P.O. Box 8496 \\ Landscape Station \\ Berkeley, CA 94707 \\ Sample back issue $\$ 3.00$
}

\section{PHILOSOPHICAL ACTIVISM NEEDS YOUR SUPPORT!}

